Article

\title{
Risks and Opportunities of Direct Democracy: The Effect of Information in Colombia's Peace Referendum
}

\author{
Juan Masullo ${ }^{1}$ and Davide Morisi ${ }^{2, *}$ \\ ${ }^{1}$ Department of Politics and International Relations, Oxford University, Oxford, OX1 3UQ, UK; \\ E-Mail: juan.masullo@politics.ox.ac.uk \\ ${ }^{2}$ Collegio Carlo Alberto, Turin 10122, Italy; E-Mail: davide.morisi@carloalberto.org \\ * Corresponding author
}

Submitted: 14 December 2018 | Accepted: 16 April 2019 | Published: 27 June 2019

\begin{abstract}
Voting decisions in high-stakes referendums can have crucial consequences for the fate of national governments and the implementation of major reforms. Prior studies have found that referendum campaigns can substantially influence their outcomes. Yet few have taken into account the fact that the effect of campaign arguments depends on a number of factors, including individual knowledge levels and the degree of uncertainty surrounding the alternatives on the ballot. In this study we investigate how political knowledge and campaign arguments stressing risks and opportunities influenced vote choice in Colombia's 2016 peace referendum. Drawing on a nationally representative survey (Study 1) and an original experiment (Study 2), we find that stressing the opportunities that the peace deal could bring to the country, rather than the risks associated with failing to conclude it, increased the probability that Colombians voted Yes in the referendum. While highly knowledgeable voters were more likely to support the deal than those with little knowledge, we find that pro-referendum opportunity arguments reduced the gap between these two groups by increasing the likelihood of a Yes vote among those with little knowledge. These findings contribute to research on voting behavior and campaign effects in direct democracies. Additionally, by exploring the crucial issue of attitudes towards peace, our findings also have important implications for countries trying to secure citizens' approval of high-stakes issues-such as negotiating the end of decades of war-through democratic instruments.
\end{abstract}

\section{Keywords}

attitudes towards peace; Colombia; information processing; peace agreements; political knowledge; referendum campaigns; voting behavior

\section{Issue}

This article is part of the issue "The Politics, Promise and Peril of Direct Democracy", edited by "Todd Donovan (Western Washington University, USA).

(C) 2019 by the authors; licensee Cogitatio (Lisbon, Portugal). This article is licensed under a Creative Commons Attribution 4.0 International License (CC BY).

\section{Introduction}

Using direct democratic consultations (such as referendums) as a tool of political decision-making-on a range of issues from the implementation of new policies to the approval of constitutional reforms-remains controversial. While critics of direct democracy have often claimed that citizens are not sufficiently qualified to partici- pate directly in policy making (Budge, 1996; Matsusaka, 2003), others have provided evidence that citizens can make competent decisions in consultations in the United States (Bowler \& Donovan, 1998), Switzerland (Colombo, 2018; Kriesi, 2005), and various European countries (Hobolt, 2009). ${ }^{1}$ The results of at least three controversial referendums that took place in 2016 in countries as diverse as the UK (on whether to remain in the EU), Italy

\footnotetext{
${ }^{1}$ For a review of the consequences of the use of referendums in modern democracies, see Qvortrup (2005).
} 
(on a constitutional reform) and Colombia (on a peace agreement between the government and the country's main rebel group) have reignited the debate on the legitimacy of direct democracy when it comes to voting on crucial matters.

The consequences of referendums are also a matter of contention. There is evidence that direct-democratic initiatives can spur political engagement (see, for example, Tolbert, Grummel, \& Smith, 2001; Donovan, Tolbert, \& Smith, 2009), but research from Latin American countries with a strong tradition of presidentialism shows that populist presidents can use referendums to manipulate the consensus and undermine legislative opposition (Breuer, 2007, 2009; Durán-Martínez, 2012; Walker, 2003). ${ }^{2}$ This debate, and the increasing popularity of direct democracy worldwide (Altman, 2011), highlights the importance of investigating how citizens make voting decisions on high-stakes referendum proposals. In this study we empirically examine the determinants of voting behavior in referendums, concretely exploring whether information influences citizens' support for this type of consultations.

There is recent evidence that the information delivered during referendum campaigns can significantly affect voting behavior (Christin, Hug, \& Sciarini, 2002; Colombo, 2018; De Vreese, 2007; Gherghina \& Silagadze, 2019; Hobolt, 2005; Kriesi, 2005). Yet the question of whether campaign arguments can have asymmetric effects in direct democratic consultations has been largely overlooked (LeDuc, 2002; Morisi, 2016). Referendums contain two intrinsically different vote choices: citizens can either vote Yes to an uncertain change or No to maintain the status quo. Given the unknown potential effects of the proposed change, campaign messages can be expected to have differential effects when they focus on the consequences of a referendum proposal. How do voters react to arguments that stress the risks or opportunities related to the outcome of a direct democratic consultation? Furthermore, it is unclear whether the effects of these campaign messages differ depending on individuals' levels of knowledge, given that relatively uninformed voters tend to prefer to maintain the status quo compared to those who are more politically sophisticated (Barber, Gordon, Hill, \& Price, 2017; Bowler \& Donovan, 1998; Christin et al., 2002; Kriesi, 2005). Can information balance the gap between voters with low and high levels of political knowledge with regard to support for a referendum proposal?

We address these questions by focusing on the referendum proposed by Colombia's former president, Juan
Manuel Santos, in October 2016 to obtain popular approval for a peace agreement his government had negotiated with the rebel group of the Revolutionary Armed Forces of Colombia (FARC) over a period of about six years. The decision to either approve or reject the deal involved various risks and opportunities. While supporters of the agreement chiefly framed it as an opportunity to end over five decades of civil war, the opposition stressed the risks of admitting the members of a "terrorist group" into Colombia's political system and society.

To investigate the role of both information and political knowledge in influencing voting preferences, we analyze two data sources: a nationally representative survey that was fielded by the Latin American Public Opinion Project (LAPOP) in the two months preceding the referendum (Study 1), and an experimental study that we conducted shortly before the vote with a convenience sample of voters (Study 2). Our findings show that stressing the opportunities of the peace deal increased the probability that citizens voted Yes in the referendum. Although highly knowledgeable voters were more likely to support the deal than those with low levels of knowledge, prodeal opportunity arguments reduced the gap between these two groups by increasing the likelihood of a Yes vote among those with less political knowledge. Campaign arguments that stressed the risks involved in the peace agreement or the opportunities associated with maintaining the status quo did not affect voting preferences. These findings contribute to our knowledge of voting behavior and campaign effects in direct democracy, and, by examining the crucial issue of attitudes towards peace, have important implications for countries that aim to strengthen peace settlements and implement conflict resolution reforms by involving the population through democratic mechanisms.

\section{The Colombian Peace Agreement}

After several failed attempts to sign a peace agreement with FARC, ${ }^{3}$ in 2012 the Colombian government-led by Santos-started a new round of negotiations with the insurgents and agreed to an agenda that defined six key issues for negotiation. ${ }^{4}$ In January 2013 , as the negotiations progressed, Santos proposed a plebiscite to approve any potential agreement, even if he was not legally mandated to so do. ${ }^{5}$ After four years of intense talks and several setbacks and delays, in June 2016 both parties announced a bilateral ceasefire and defined the conditions for the demobilization and reintegration of FARC. In September they announced and signed their

\footnotetext{
2 For a positive example of referendums as a counter-power tool in Bolivia, see Welp \& Lissidini (2016).

${ }^{3}$ Before 2012, three different Colombian governments unsuccessfully attempted to negotiate with FARC: in 1984, 1991 and 1998. For a brief description of these negotiations, see González Posso (2004). For recent summaries and analysis of the Colombian conflict more generally, see Steele (2017, Chapters 2 and 3) and Vargas and Caruso (2014).

${ }^{4}$ The six items included comprehensive rural reform; political participation by former rebels; the cessation of hostilities and disarmament; a comprehensive solution to the illicit drugs problem; establishment of a special system for truth, justice, reparations and non-repetition; and, mechanisms for the implementation and verification of the agreement.

${ }^{5}$ According to Colombian legislation, the consultation was defined as a "plebiscite" because the minimum turnout threshold was reduced to 13 percent from the 25 percent required for referendums. For consistency with the majority of studies on direct democracy, we refer to this consultation as a referendum.
} 
final agreement. The main aim of the deal was to end conflict with the country's strongest rebel group fighting one of the longest-running internal wars in the Western hemisphere, which killed approximately 220,000 people between 1958 and 2012 (Grupo de Memoria Histórica, 2013).

The popular consultation took place on October 2 . Despite opinion polls suggesting wide support, the peace agreement was rejected by a razor-thin margin: "No" won with 50.2 percent of the vote. Turnout was low, at less than 38 percent of the electorate. Following the unexpected result, the government resumed its negotiations with FARC and Congress approved a revised deal at the end of November 2016.

Throughout the negotiations and during the referendum campaign, two factions emerged among elites: Santos and his administration strongly supported the negotiations and urged the population to vote Yes, while Álvaro Uribe Vélez, a very popular former president who is credited with militarily weakening the FARC, fiercely opposed the process and campaigned for No. Matanock and Garbiras-Díaz (2018, p. 15) described the referendum as "a battle of narratives between divided elites".

The No camp criticized the provisions of the peace agreement as unjustified concessions to the rebels, and emphasized the risks of promoting a culture of impunity in which "terrorists" could participate in politics. The Yes camp repeatedly emphasized the potential risks of not approving the agreement, such as returning to deadly cycles of violence and years of armed conflict. They somewhat vaguely framed the deal as a historical opportunity for peace, reconciliation, and social and economic development without citing specific provisions of the agreement. As Arjona (2016) noted, the government failed to explain how the components contained real opportunities for change.

Given the complexity of the six-year negotiation process that led to a final agreement of almost 300 pages touching on a large variety of crucial themes for the future of the country, commentators predicted that information about the peace deal would be decisive in the plebiscite. However, current explanations of why the referendum was rejected-and, more generally, of the determinants of attitudes towards the peace deal-have focused on factors other than information and knowledge.

For example, some scholars have examined the "violence-voting nexus", following the lead of Weintraub, Vargas and Flores (2015) who provided evidence from presidential elections that residents of areas with moderate levels of violence tend to support "peace candidates" more than those from areas with very high or very low levels of violence. In an early analysis shortly after the referendum, Arjona (2016) showed that voters living in areas that suffered more from violent conflict were more likely to support the deal (see also Fergusson \& Molina, 2016). Similarly, Kreiman and Masullo (2019) found that victims of FARC tended to support the referendum more than victims of the paramilitaries.
By contrast, Liendo and Braithwaite (2018) found that attitudes towards the peace process were driven more by political preferences than by experience of violence. This is in line with evidence showing that in Colombia and Latin America more broadly, political support for the president tends to correlate with approval of the issues proposed in direct-democratic consultations (Breuer, 2007; Durán-Martínez, 2012; Ruth, Welp, \& Whitehead, 2017). Furthermore, Matanock and GarbirasDíaz (2018) found that rebel endorsement of the agreement's electoral provisions diminished support for it.

We expect that the "information aspect" of the campaign might also play an important role in explaining voting decisions in the Colombian referendum. If the campaign leading up to the referendum was really a "battle of narratives" between deeply divided elites, to what extent did the arguments from both camps influence voting decisions? In the next section we advance different theoretical expectations building on research on campaign effects in direct democracy, which we then test with both observational and experimental data.

\section{Political Knowledge and Information Effects in Referendum Campaigns}

Since early research on public opinion, political knowledge has been considered one of the main determinants of political reasoning (for a review, see Delli Carpini \& Keeter, 1997). Numerous studies have shown that political sophistication and political knowledge moderate voters' decision-making processes (e.g., Jerit, Barabas, \& Bolsen, 2006; Slothuus \& De Vreese, 2010; Zaller, 1992). In the specific context of direct democracy, there is evidence that undecided and less informed voters (Bowler \& Donovan, 1998, p. 49; Christin et al., 2002) are more likely to vote No to a referendum proposal compared to those with high levels of political knowledge. Similarly, experimental evidence confirms that support for the status quo in voting on social issues is strongest among the least-informed individuals (Barber et al., 2017). In line with this evidence, and considering claims that the lack of knowledge played a central role in driving the results of the Colombian referendum (Arjona, 2016; Idler, 2016), we expect voters with high levels of political knowledge to be more likely to vote Yes in the peace referendum than those with low levels (Hypothesis 1).

While we hypothesize that individual differences in political knowledge correlate with voting preferences in direct democracy, we can expect that voters also react to campaign messages supporting both sides of a referendum campaign, and that the influence of such messages is moderated by their pre-existing levels of knowledge. Drawing on the literatures on framing (for a review, see Chong \& Druckman, 2007) and information effects in elections (e.g., Alvarez, 1997; Bartels, 1996) and referendum campaigns (Christin et al., 2002; De Vreese, 2007; Hobolt, 2009; Kriesi, 2005), we can derive two competing expectations about how messages that stress the 
risks and opportunities involved in a referendum proposal should influence voting preferences.

The first expectation draws on prospect theory and studies on loss aversion (Kahneman, Knetsch, \& Thaler, 1991). Research in political and social psychology has stressed that negative information tends to have a stronger influence on political decisions than positive information (for a review, see Peeters \& Czapinski, 1990; Soroka, 2014), partially because of a "negativity bias" in individuals' reactions to negative events compared to positive ones (Rozin \& Royzman, 2001). Evidence from health communication points in this direction, indicating that by motivating preventive health behavior, "loss-framed" messages are more persuasive than "gain-framed" ones (Schneider et al., 2001). Additional evidence confirms that negative economic information has a stronger impact on individuals' attitudes than positive information (Soroka, 2006). Building on these premises, we argue that if "losses loom larger than gains" (Kahneman \& Tversky, 1984), "risk arguments" (which stress the risks related to either accepting or rejecting a referendum proposal) should be more persuasive than "opportunity arguments" (which highlight the opportunities involved on both sides of a referendum) (Hypothesis 2a).

The competing expectation draws on the "uncertainty-reduction" effect of information identified in elections (Alvarez \& Brehm, 2002) and referendums (Hobolt, 2009). The evidence shows that arguments used in direct democratic campaigns can influence voting preferences not only by persuading voters, but also by modifying their levels of uncertainty (LeDuc, 2002; Morisi, 2016). A key assumption is that the value that voters attribute to a referendum proposal increases as the uncertainty related to the proposal decreases (Hobolt, 2009, pp. 40-50). Therefore, campaign arguments that stress the opportunities of either accepting a referendum proposal or maintaining the status quo should be particularly persuasive because they directly reduce the uncertainty related to these options. However, risk arguments are based on a somewhat more complex reasoning. They indirectly promote referendum options by pointing out the drawbacks of their alternatives and predict what could happen if the referendum is approved/rejected; thus they are less likely to reduce uncertainty. Following this reasoning, therefore, we can expect opportunity messages to be more persuasive than risk messages, because they reduce the uncertainty related to referendum options (Hypothesis $2 b$ ). In addition, we can expect such an effect to be particularly large when the arguments stress the opportunities related to approving (instead of rejecting) a referendum proposal, since in most casessuch as Colombia's peace referendum - the uncertainties related to the "change option" (i.e., voting Yes) are higher than those associated with maintaining the status quo (Hobolt, 2009, pp. 40-50; LeDuc, 2002).
Lastly, we can assume that individual political knowledge should moderate the effect of campaign arguments. Kam (2005) has argued that voters' pre-existing knowledge levels influence the reception of campaign messages. More specifically, experimental evidence has shown that voters with low levels of knowledge are more likely to be influenced by the content of campaign messages than those with high levels (Lee, Herr, Kardes, \& Kim, 1999; Schuck \& De Vreese, 2006; Slothuus \& De Vreese, 2010). One of the main reasons for this finding is that people with low knowledge lack the necessary "ammunition with which to counterargue" persuasive messages (Taber $\&$ Lodge, 2006, p. 757). Thus, we hypothesize that campaign arguments-regardless of whether they focus on the risks or the opportunities of the referendum - should have a stronger effect on those with low political knowledge compared to those with high knowledge (Hypothesis 3).

In the next two sections we empirically test these expectations using data from two separate studies-a nationally representative survey to test $\mathrm{H} 1$ (Study 1) and an experiment conducted in the weeks preceding the Colombian referendum to test the other hypotheses (Study 2). While Study 1 allows us to identify the determinants of voting preferences and in particular the role of political knowledge in a representative sample of Colombian voters, Study 2 provides causal evidence of how campaign arguments influenced support for the peace agreement.

\section{Study 1: LAPOP Survey}

\subsection{Data and Measures}

Between 2016 and 2017, the LAPOP of Vanderbilt University conducted the most recent round of the Americas Barometer surveys. This article analyzes data from the survey conducted in Colombia between August 3 and October 29, 2016 in conjunction with the Observatorio de la Democracia of the Universidad de los Andes, which included questions on the peace referendum. Face-toface interviews were conducted using a national probability sample of voters that was selected using a multistage probability design with geographical regions, municipality size, and urbanization as the main strata. Our analysis excludes respondents who were interviewed on the day of the referendum or afterwards ( $N=207)$, which leaves us with a total sample of 1,356 respondents (a complete description of the variables, summary statistics and question wording are available in the Appendix.)

Our main dependent variable is a measure of respondents' voting intentions in the event that a referendum was used to ratify the agreement, which we recode as a binary choice variable with a value of 1 for those who intended to vote Yes, and a value of 0 otherwise (excluding "Don't know" and no response) ${ }^{6}$. In alternative models,

\footnotetext{
${ }^{6}$ The question reads as follows: "in the event that a popular vote will be held to endorse the peace agreement between the government and the FARC, how would you vote?" Possible answers included: "I would vote in favor", "I would vote against", "I would not vote", “Don't know”, "No reply".
} 
we use either a dummy variable with Yes votes versus No votes (excluding all other options), or a choice variable that includes three categories (voting Yes, voting No, and not voting).

To measure political knowledge, we combined the responses to three questions about factual knowledge in an additive index, which we subsequently dichotomized into two categories to increase comparability with the experimental design: a "high knowledge" category (corresponding to the one-third of respondents who responded correctly to all three questions) and a "low knowledge" category for all others ${ }^{7}$. In Appendix A, we replicate the analysis using two alternative measures of knowledge: self-assessed knowledge level or frequency of attention to political news in the media.

In addition to the measures of political knowledge, in the regression analysis we control for standard demographics such as age, education, and in particular gender, since research has shown that women are less likely to support referendum proposals that involve a high degree of uncertainty (Verge, Guinjoan, \& Rodon, 2015). We also include other covariates that might influence both voting intentions and knowledge, such as monthly household income and respondents' self-perception of their personal economic situation, since previous studies show that economic evaluations (Clarke, Kornberg, \& Wearing, 2000) and economic expectations (De Vreese \& Boomgaarden, 2005) are key determinants of vote choice in direct democratic consultations in Europe. Lastly, we control for trust in the president and vote choice in the 2014 presidential election, since prior studies have found that trust in the government (Kriesi, 2005), government approval (De Vreese \& Boomgaarden, 2005), and partisan considerations (e.g., Christin et al., 2002; Colombo \& Kriesi, 2017; Kriesi, 2005) are strong predictors of voting behavior in referendums (on presidential approval, see also Breuer, 2007, 2009; Durán-Martínez, 2012; Walker, 2003).

\subsection{Results}

Figure 1 displays the results from our full logistic regression model of the intention to vote Yes in the referendum on the peace agreement. As the plot shows, political knowledge is positively and significantly correlated with the probability of voting Yes, even when all covariates are included in the model. Depending on model specifications (see Table $A 2$ in Appendix A), those with a high level of political knowledge are 9-11 percentage points more likely to vote Yes than those with low levels of political knowledge, keeping all other factors constant. Alternative specifications confirm the existence of a substantial and significant correlation: those who perceive themselves as having a very high level of political knowledge are 14-19 percentage points more likely to vote Yes than those with a very low level of perceived political knowledge, while those who look for political news in the me- dia on a daily basis are 11-16 percentage points more likely to vote Yes than those who never look for news (see Table A4 in Appendix A). These findings confirm our expectation $(\mathrm{H} 1)$ that a higher level of political knowledge is associated with a higher probability of supporting the referendum proposal.

In alternative binomial logistic regressions, we find that a high level of knowledge also correlates with the intention to vote Yes compared to the intention to vote No, although the effect is marginally significant at the 0.1 level (see Table A5 and Figure A1 in Appendix A). When we run multinomial logistic regressions, however, we find that a high level of knowledge significantly correlates with Yes votes compared to non-voters, but not to No votes. These results suggest that the positive effect of knowledge on support for the peace agreement operates mainly through a "mobilization channel", in line with evidence that political knowledge influences turnout (Larcinese, 2007). In other words, those who know more about politics are more likely to both vote in the referendum and to vote Yes compared to those who know less, while political knowledge has no effect on the probability of voting No.

In addition to highlighting the role of knowledge, the regression results reveal other determinants of voting in the Colombian referendum that resemble those identified in research on other direct democratic consultations. Figure 1 shows that the strongest predictors of voting preferences are trust in the president and past vote for President Santos: moving from no trust at all to complete trust in the president increases the chances of a Yes vote by 45 percentage points, while those who voted for Santos in the 2014 election are 21 percentage points more likely to vote Yes than those who did not vote. Additional models show that presidential approval is also a crucial determinant of Yes votes (see Table A3 in Appendix A). These findings support previous evidence that presidents play a key role in influencing voting behavior in referendums in Latin America (Durán-Martínez, 2012). In addition, the findings confirm that those whose economic situation improved over the past 12 months are significantly more likely to vote Yes than those whose economic situation remained stable, and that women are less likely to vote for a change than men-a finding that confirms the existence of a gender gap in support for direct democratic proposals involving a degree of uncertainty (Verge et al., 2015).

\section{Study 2}

\subsection{Experimental Sample}

Although the analysis of the LAPOP data allows us to test the effect of political knowledge in a representative sample of voters, the observational nature of the survey prevents us from exploring the potential causal effects of in-

\footnotetext{
${ }^{7}$ The three questions are: "What is the name of the current president of the United States of America?"; "On what continent is Nigeria?"; and "How long is the presidential term in Colombia?". Replies have been coded with a value of 1 for correct answers, and a value of 0 otherwise.
} 


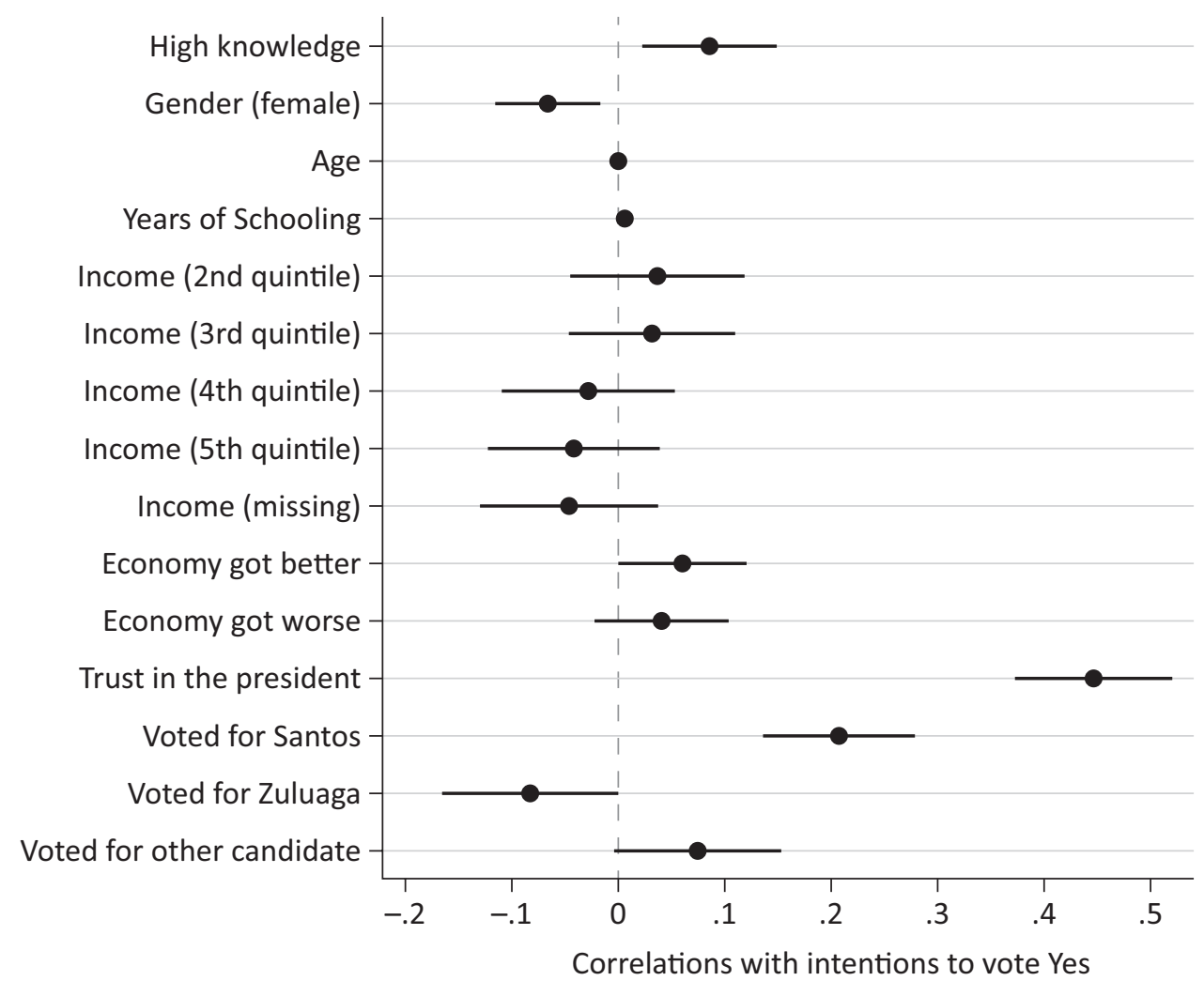

Figure 1. Determinants of intentions to vote Yes to the peace agreement. Notes: Average marginal effects based on logistic regressions (Model 3 in Table A2 in Appendix A, $N=1261$ ). Dependent variable: intention to vote Yes in the peace agreement referendum. Horizontal lines correspond to 95 percent confidence intervals.

formation on voting preferences. How did voters react to the different arguments highlighting the opportunity and risks involved in the Colombian peace agreement?

To answer this question and address our theoretical predictions, we conducted an experimental study in the few days between the signature of the peace agreement in Cartagena (September 26, 2016) and the day of the referendum (October 2, 2016). The experiment was fielded online and included a convenience sample of 478 eligible Colombian voters, recruited mostly through readers of the magazine Vice Colombia and students of Javeriana University. The median age of our sample was 32 years, and the respondents were 58 percent women. Our sample differed importantly from the average Colombian citizen, since it included mostly residents of Bogota (66 percent), university students (43 percent), and a large share of supporters of the peace agreement ( 79 percent of the participants in the control group intended to vote Yes). Balance tests indicate that there are no major differences between the treatment groups and the control group with regard to the socio-demographic dimensions recorded in the study (see Table C2 in Appendix C).

Considering the nature of our experimental sample, we should necessarily be cautious about extending the results from Study 2 to the entire Colombian electorate. Although recent evidence shows that experimental estimates from convenience samples (including student samples) are similar to those obtained from national sam- ples (Coppock, 2018; Coppock, Leeper, \& Mullinix, 2018; Druckman \& Kam, 2011; Mullinix, Leeper, Druckman, \& Freese, 2016), it is possible that the effect size of risk and opportunity arguments would differ within a populationbased sample. For example, we might expect the information effects to be larger if our sample included a larger share of low-knowledge voters (in line with the evidence reviewed above), or we might expect the effect of propeace agreement arguments to be smaller if our sample included more opponents of the peace deal, in line with the theory of motivated reasoning (Lodge \& Taber, 2013), as discussed below.

However, we do not envisage strong reasons why the direction of the average treatment effects should be substantially different within a nationally representative sample. Why would a group of voters, including a large share of young university students, react to risk and opportunity arguments in a markedly different way than the general electorate? Although we cannot address this question directly, we inspected whether students' voting patterns differed significantly from non-students using LAPOP data. The analysis indicates that: a) being a student does not correlate with the probability of voting Yes, once we control for the other factors included in previous analysis; b) students do not differ significantly in their voting intentions from the rest of the sample (see Table A7 in Appendix A); and c) the determinants of Yes votes are substantially the same for students and 
non-students, although the precision of the estimates changes due to the small number of students in the LAPOP survey (see Figure A2 in Appendix A). For these reasons, we believe that our experimental study can provide valid estimates, even if we should keep in mind the limitations related to a convenience sample of voters.

\subsection{Experimental Design}

After replying to a few socio-demographic questions, the participants in Study 2 were randomly assigned to one of five experimental conditions, as summarized in Table 1. Those assigned to the treatment groups read a short argument of around 70 words that was either in favor (pro argument) or against (con argument) the peace agreement. The texts highlighted either the risks or the opportunities of both sides of the referendum campaign, and were created on the basis of the main arguments used in the campaign debate in major news outlets. Thus, the participants were not exposed to fictional arguments, but only to publicly available information. Deception was not used in the experiment.

To illustrate, the following is the English translation of the argument stressing the opportunities of the peace deal that we presented in Group 1 (the complete list of arguments and the original wording in Spanish is available in Appendix E):

Those who support the Yes argue that voting Yes in the referendum constitutes a historical opportunity to end violence in the country. They contend that it is key to bringing peace to the rural areas and for the displaced to come back to their lands, without poverty, landmines and illicit crops. Victims will know what happened with their beloved ones, will be repaired and non-repetition will be guaranteed. They see in the referendum an opportunity to decide if we want to end the war.

After reading the text, we asked the participants whether they intended to vote Yes or No to the proposed peace agreement. Those assigned to the control group replied to the same question without reading any information. Voting intentions in the control condition therefore serve as a baseline against which we measure eventual changes in the treatment conditions. Participants then replied to two questions about basic facts concerning the peace agreement. Those who replied correctly to both questions (70 percent) were assigned a value of 1 ("high knowledge"), while the other participants (30 percent) were assigned a value of 0 ("low knowledge").

\subsection{Results}

Table 2 summarizes the results of different logistic regressions in which we estimate whether the intention to vote Yes differed by group assignment, with the control group set as the reference category. As Model 1 shows, pro arguments that stressed opportunities related to the peace agreement significantly increased participants' likelihood of voting Yes. However, pro arguments that stressed the risks of a No vote and the arguments used by the opponents of the peace agreement (con arguments) had no influence on voting preferences. The results are substantially similar in Model 2, in which we introduce socio-demographic covariates to increase the precision of the estimates (Angrist \& Pischke, 2009, pp. 23-44).

The results from the regression analysis therefore partially support $\mathrm{H} 2 \mathrm{~b}$ (but not $\mathrm{H} 2 \mathrm{a}$ ) that campaign arguments should be more persuasive when they highlight the opportunities (instead of the risks) related to a referendum proposal, although the effect applies only to the arguments that support a Yes vote. By contrast, the arguments against the peace deal do not seem to influence participants' voting preferences significantly.

Next, we tested whether the observed effects differed depending on whether the participants correctly answered factual questions related to the peace agreement. First, analysis of the participants in the control condition confirms that those with high levels of knowledge were significantly more likely to vote Yes than those with low levels, which is in line with the survey results. However, the negative interaction coefficients in Models 3 and 4 indicate that the effect of pro-deal opportunity arguments is significantly lower for those with high political knowledge compared to those with low political knowledge. The difference between these two groups of voters is evident when we plot the average marginal effects in Figure 2. If we first consider all the participants, the left-hand plot of Figure 2 confirms that pro-opportunity arguments increase the probability of voting for the peace agreement by 13 percentage points compared to no information. When we break down the effects by level of knowledge (right-hand plot), we find that pro-opportunity arguments increase the likelihood of voting Yes by 30 percentage points among lowknowledge participants, while the effect is not significant among their high-knowledge counterparts. These find-

Table 1. Design of the Experiment.

\begin{tabular}{ccccc}
\hline No information & \multicolumn{2}{c}{ Opportunity arguments } & \multicolumn{2}{c}{ Risk arguments } \\
\hline Control group & Group 1 (PRO) & Group 2 (CON) & Group 3 (PRO) & Group 4 (CON) \\
\hline & Opportunity & Opportunity & Risk & Risk \\
of voting Yes & of voting No & of voting No & of voting Yes \\
$(\mathrm{N}=95)$ & $(\mathrm{N}=94)$ & $(\mathrm{N}=96)$ & $(\mathrm{N}=96)$ & $(\mathrm{N}=97)$ \\
\hline
\end{tabular}


Table 2. Treatment effects on support for peace agreement.

Intentions to vote Yes

Treatment groups (ref: control)

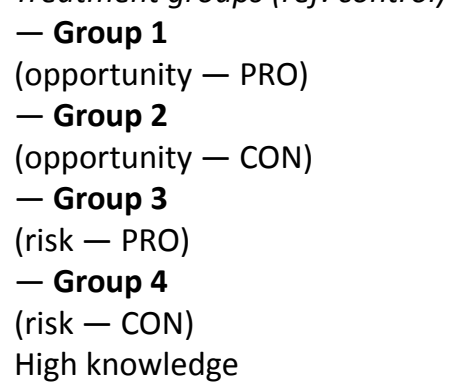

Group $1 \times$ High knowledge

Group $2 \times$ High knowledge

Group $3 \times$ High knowledge

Group $4 \times$ High knowledge

Gender (female)

Age

High education

Employment (ref $=$ working, not student)

- Unemployed, not student

- Student

Living in Bogotá

Constant
(1)

(2)

$1.053^{* *}$
$(0.447)$
0.288
$(0.372)$
0.214
$(0.367)$
0.636
0.636
$0.822^{*}$
$(0.474)$
0.246
$(0.401)$
$-0.002$
$(0.400)$
0.455
0.455
0.388
$(0.302)$

(3)

$2.391^{* *}$
$(1.079)$

0.578

$(0.549)$

0.550

$(0.578)$

1.004

1.004

$1.466 * * *$

(0.551)

$-2.314^{*}$

(1.229)

$-0.888$

$(0.786)$

$-1.008$

(0.793)

$-1.061$

(0.861)

0.566 *

(0.295)

$-0.028^{* *}$

(0.011)

$0.591 * *$

(0.292)

$-0.334$

(0.397)

$-0.065$

$(0.361)$

0.037

(0.297)

$1.753 * * *$

(0.676)

472

\begin{tabular}{lllll}
\hline Pseudo $^{2}$ & .018 & .096 & .042 & .109 \\
$\mathrm{~N}$ & 478 & 472 & 472 & 472 \\
\hline
\end{tabular}

(4)

2.498**

(1.116)

0.789

(0.594)

0.349

(0.618)

0.978

0.978

1.240**

(0.595)

$-2.502 * *$

$(1.272)$

$-1.084$

(0.829)

$-0.756$

(0.832)

$-1.020$

(0.907)

0.576 *

$(0.302)$

$-0.031 * * *$

(0.012)

$0.608^{* *}$

$(0.295)$

$-0.251$

(0.409)

$-0.050$

(0.362)

$-0.036$

(0.303)

$1.462^{* *}$

$(0.702)$

Notes: $* \mathrm{p}<0.1,{ }^{* *} \mathrm{p}<0.05, * * * \mathrm{p}<0.01$. Coefficients are log-odds based on logistic regressions (for average marginal effects see Table C3 in Appendix C). Dependent variable: intention to vote Yes versus other options. Standard errors in parentheses.

ings support the expectation that information about a referendum proposal has a greater impact when voters know less about the content of the proposal (H3).

Lastly, we investigated why the arguments used by the opponents of the referendum did not reduce support for the peace agreement within our sample. The analysis in Appendix D suggests that the presence of disconfirmation bias and the complexity of risk messages might explain this lack of effect.

\section{Conclusions}

The results of a recent wave of direct-democratic consultations that took place in Europe and Latin America has made clear that voting decisions in high-stakes referendums can have substantial consequences for the fate of national governments and the implementation of major reforms. The case of the 2016 Colombian referendum reveals that opening up a peace process to direct consultation with the population can potentially derail years of negotiation, even in a country where one would expect wide popular support for measures to end a long and bloody civil war (Flores \& Vargas, 2018). Moreover, although the government eventually managed to ratify the peace deal despite the opposition of a (minimal) majority of Colombian voters, policy experts argue that peace in Colombia cannot be maintained without popular consent (e.g., Llorente, 2016). Even if the deal is now sealed, 

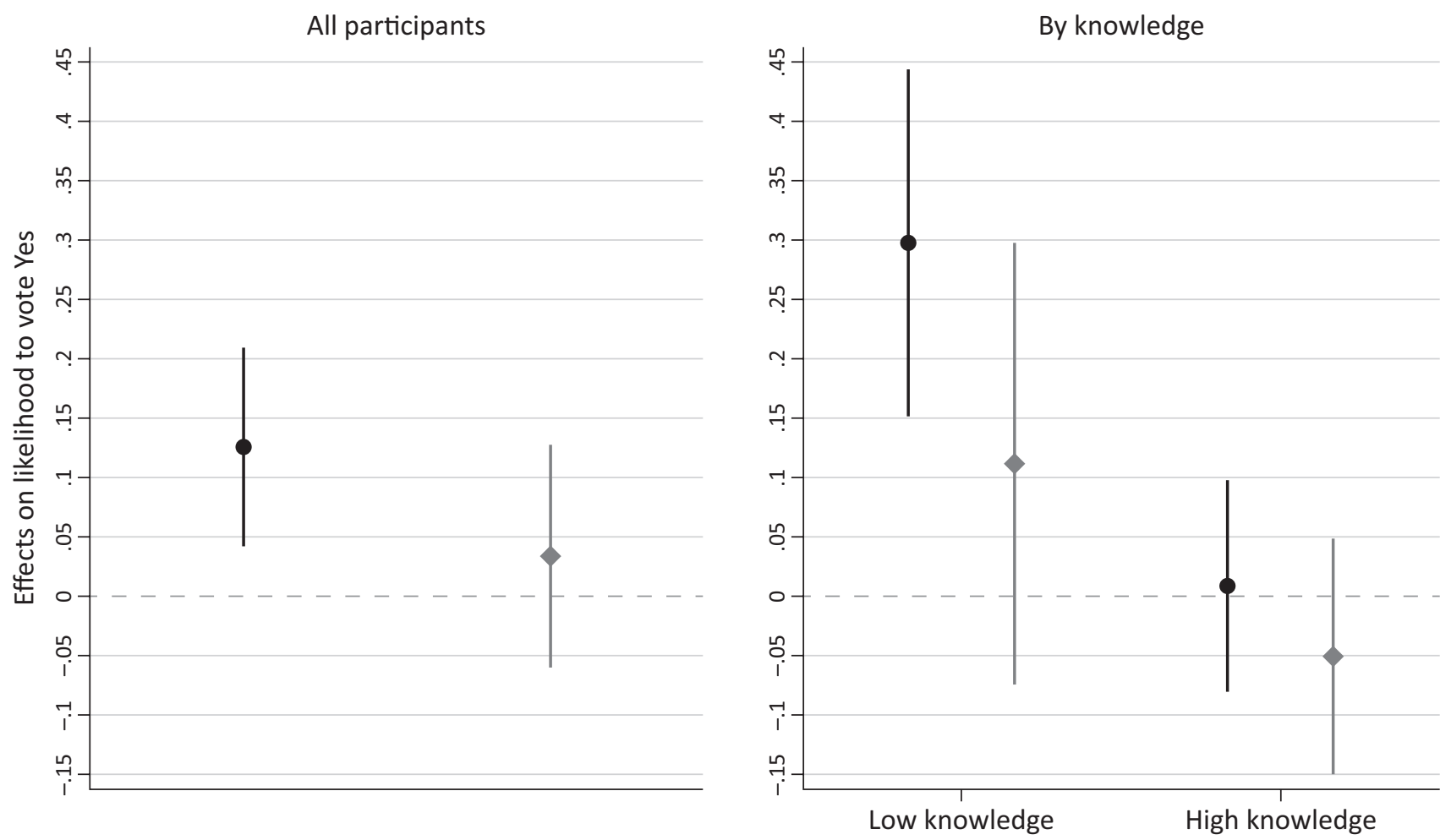

Opportunity argument (PRO)

$\diamond$ Risk argument (PRO)

Figure 2. Effects of pro arguments on intention to vote Yes. Notes: Marginal effects based on models 1 and 3 in Table 2. Value 0 on $\mathrm{Y}$-axis equal to control group. Vertical bars correspond to 90 percent confidence intervals.

successful implementation is likely to hinge largely on popular support, especially after Iván Duque, who has been openly critical of the peace agreement, became president. With so much at stake, understanding the determinants of political attitudes towards peace and voting behavior more generally becomes even more relevant for the country's future.

Our findings provide evidence that information plays a crucial role in influencing voting preferences in highstakes referendums. More specifically, they indicate that voters in this type of direct democratic consultation care more about the opportunities that approving a proposal could potentially imply for them and their country than the possible risks associated with its rejection. Furthermore, we show that political knowledge plays a central role in both determining voting preferences and in the reception of information in two ways. First, we find that in the 2016 Colombian referendum, higher levels of political knowledge are associated with a higher probability of voting Yes. Knowledge seems to influence support for the proposal mostly by mobilizing potential Yes voters, since those who know more about politics are more likely to both vote and to vote Yes than those who know less about politics. Second, positive arguments that stress the opportunities of the referendum proposal have a greater influence on poorly informed voters. This suggests that when a referendum concerns a salient but complex pro- posal, information is especially crucial for those with low levels of political knowledge.

It is important, however, to highlight the limitations of the sample in Study 2, which included a higher share of "Yes voters" and highly educated voters than the general population. Therefore, we cannot exclude the possibility that our "con arguments" would have had a different effect in a representative sample with a larger share of No voters. In line with the theory of motivated reasoning (e.g., Lodge \& Taber, 2013), it might be the case that campaign arguments are persuasive as long as they "resonate" with respondents' prior attitudes towards a referendum proposal. Besides these limitations, the fact that we do find information effects in a "hard case" that is, a campaign in which the stakes were high and in a study conducted just a few days before the crucial vote-strengthens the contribution of our findings.

Finally, the implications of our findings for securing peace making and peace building extend beyond Colombia. Although attempting to seal a peace deal with a referendum is not a common strategy, the number of civil wars in countries where elections take place is growing (Matanock \& García-Sánchez, 2017). This suggests that understanding how to successfully harness (electoral) support for peace might be crucial for political leaders in conflict-affected countries working to end armed strife through negotiated settlements. For Colombia and other 
countries facing the historical opportunity to end war through democratic solutions, understanding citizens' attitudes about the risks and opportunities involved in a peace process is a key step towards securing broad popular support for a peaceful future.

\section{Acknowledgments}

We are grateful to all those who kindly took the time to answer our questionnaire; to Juan Camilo Maldonado, Manuel Salamanca, Lucas Sánchez and Vice Colombia for supporting us with the recruitment of participants; and to Javier Fernando Torres and Andrés Vargas for providing advice to improve the study.

\section{Conflict of Interests}

The authors declare no conflict of interests.

\section{References}

Altman, D. (2011). Direct democracy worldwide. Cambridge: Cambridge University Press.

Alvarez, M. R. (1997). Information and elections. Ann Arbor, MI: The University of Michigan Press.

Alvarez, M. R., \& Brehm, J. (2002). Hard choices, easy answers. Princeton, NJ: Princeton University Press.

Angrist, J. D., \& Pischke, J.-S. (2009). Mostly harmless econometrics: An empiricist's companion. Princeton, NJ: Princeton University Press.

Arjona, A. (2016). War dynamics and the "NO" vote in the Colombian referendum. Political Violence at a Glance. Retrieved from http://politicalviolence ataglance.org/2016/10/20/war-dynamics-and-theno-vote-in-the-colombian-referendum

Barber, M., Gordon, D., Hill, R., \& Price, J. (2017). Status quo bias in ballot wording. Journal of Experimental Political Science, 4(2), 151-160.

Bartels, L. M. (1996). Uninformed votes: Information effects in presidential elections. American Journal of Political Science, 40(1), 194-230.

Bowler, S., \& Donovan, T. (1998). Demanding choices. Opinion, voting and direct democracy. Ann Arbor, MI: University of Michigan Press.

Breuer, A. (2007). Institutions of direct democracy and accountability in Latin America's presidential democracies. Democratization, 14(4), 554-579.

Breuer, A. (2009). The use of government-initiated referendums in Latin America. Towards a theory of referendum cases. Revista de Ciencia Política, 29(1), 23-55.

Budge, I. (1996). The new challenge of direct democracy. Cambridge: Polity Press.

Chong, D., \& Druckman, J. N. (2007). Framing theory. Annual Review of Political Science, 10(1), 103-126.

Christin, T., Hug, S., \& Sciarini, P. (2002). Interests and information in referendum voting: An analysis of Swiss voters. European Journal of Political Research, 41(6), 759-776.
Clarke, H. D., Kornberg, A., \& Wearing, P. (2000). A polity on the edge: Canada and the politics of fragmentation. Peterborough: Broadview Press.

Colombo, C. (2018). Justifications and citizen competence in direct democracy: A multilevel analysis. British Journal of Political Science, 48(3), 787-806.

Colombo, C., \& Kriesi, H. (2017). Party, policy-Or both? Partisan-biased processing of policy arguments in direct democracy. Journal of Elections, Public Opinion and Parties, 27(3), 235-253.

Coppock, A. (2018). Generalizing from survey experiments conducted on mechanical turk: A replication approach. Political Science Research and Methods, 2018, 1-16. https://doi.org/10.1017/psrm.2018.10

Coppock, A., Leeper, T. J., \& Mullinix, K. J. (2018). Generalizability of heterogeneous treatment effect estimates across samples. Proceedings of the National Academy of Sciences of the United States of America, 115(49), 12441-12446.

De Vreese, C. H. (Ed.). (2007). The dynamics of referendum campaigns: An international perspective. Basingstoke: Palgrave Macmillan.

De Vreese, C. H., \& Boomgaarden, H. G. (2005). Projecting EU referendums. Fear of immigration and support for European integration. European Union Politics, 6(1), 59-82.

Delli Carpini, M. X., \& Keeter, S. (1997). What Americans know about politics and why it matters. New Haven: Yale University Press.

Donovan, T., Tolbert, C. J., \& Smith, D. A. (2009). Political engagement, mobilization, and direct democracy. Public Opinion Quarterly, 73(1), 98-118.

Druckman, J. N., \& Kam, C. D. (2011). Students as experimental participants: A defence of the "narrow data base." In J. N. Druckman, D. P. Green, J. H. Kuklinski, \& A. Lupia (Eds.), Cambridge handbook of experimental political science (pp. 41-57). Cambridge: Cambridge University Press.

Durán-Martínez, A. (2012). Presidents, parties, and referenda in Latin America. Comparative Political Studies, 45(9), 1159-1187.

Fergusson, L., \& Molina, C. (2016). Un vistazo a los resultados del plebiscito [A glance at the results of the pblebiscite]. La Silla Vacía. Retrieved from https://lasillavacia.com/blogs/un-vistazo-losresultados-del-plebiscito-58200

Flores, T. E., \& Vargas, J. F. (2018). Colombia: Democracy, violence, and the peacebuilding challenge. Conflict Management and Peace Science, 35(6), 581-586.

Gherghina, S., \& Silagadze, N. (2019). And yet it matters: Referendum campaigns and vote decision in Eastern Europe. Contemporary Politics, 25(1), 29-46.

González Posso, C. (2004). Negotiations with the FARC: 1982-2002 (Conciliation Resources, No. 14). Retrieved from https://www.c-r.org/accord-article/ negotiations-farc-1982-2002

Grupo de Memoria Histórica. (2013). ¡Basta Ya! Colombia: Memorias de guerra y dignidad [Basta ya! 
Colombia: Memories of war and dignity]. Centro Nacional de Memoria Histórica. Retrieved from http://www.centrodememoriahistorica.gov.co/ micrositios/informeGeneral

Hobolt, S. B. (2005). When Europe matters: The impact of political information on voting behaviour in EU referendums. Journal of Elections, Public Opinion \& Parties, 15(1), 85-109.

Hobolt, S. B. (2009). Europe in question. Referendums on European integration. Oxford: Oxford University Press.

Idler, A. (2016). Colombia just voted no on its plebiscite for peace. Here's why and what it means. The Washington Post. Retrieved from https://www.washington post.com/news/monkey-cage/wp/2016/10/03/ colombia-just-voted-no-on-its-referendum-forpeace-heres-why-and-what-it-means/?noredirect= on\&utm_term =.bb688d776897

Jerit, J., Barabas, J., \& Bolsen, T. (2006). Citizens, knowledge, and the information environment. American Journal of Political Science, 50(2), 266-282.

Kahneman, D., Knetsch, J. L., \& Thaler, R. H. (1991). Anomalies: The endowment effect, loss aversion, and status quo bias. The Journal of Economic Perspectives, 5(1), 193-206.

Kahneman, D., \& Tversky, A. (1984). Choices, values, and frames. American Psychologist, 39(4), 341-350.

Kam, C. D. (2005). Who toes the party line? Cues, values, and individual differences. Political Behavior, 27(2), 163-182.

Kreiman, G., \& Masullo, J. (2019). Who shot the bullets. Exposure to violence and attitude towards peace. Paper presented at All Souls Conflict Workshop, University of Oxford, UK.

Kriesi, H. (2005). Direct democratic choice. The Swiss experience. Lanham, MD: Lexington.

Larcinese, V. (2007). Does political knowledge increase turnout? Evidence from the 1997 British general election. Public Choice, 131(3/4), 387-411.

LeDuc, L. (2002). Opinion change and voting behaviour in referendums. European Journal of Political Research, 41(6), 711-732.

Lee, H., Herr, P. M., Kardes, F. R., \& Kim, C. (1999). Motivated search effects of choice accountability, issue involvement, and prior knowledge on information acquisition and use. Journal of Business Research, 45(1), 75-88.

Liendo, N., \& Braithwaite, J. M. (2018). Determinants of Colombian attitudes toward the peace process. Conflict Management and Peace Science, 35(6), 622-636.

Llorente, M. V. (2016). Peace in Colombia could not have been maintained without popular consent. New York Times. Retrieved from https://www.nytimes.com/ roomfordebate/2016/10/05/when-should-thepeoples-voice-be-trusted/peace-in-colombiacould-not-have-been-maintained-without-popularconsent
Lodge, M., \& Taber, C. S. (2013). The rationalizing voter. Cambridge; NY: Cambridge University Press.

Matanock, A. M., \& Garbiras-Díaz, N. (2018). Considering concessions: A survey experiment on the Colombian peace process. Conflict Management and Peace Science, 35(6), 637-655.

Matanock, A. M., \& García-Sánchez, M. (2017). The Colombian paradox: Peace processes, elite divisions \& popular plebiscites. Daedalus, 146(4), 152-166.

Matsusaka, J. G. (2003). Direct democracy. In C. K. Rowley \& F. Schneider (Eds.), Encyclopaedia of public choice. Dordrecht: Kluwer Academic Publishers.

Morisi, D. (2016). Voting under uncertainty: The effect of information in the Scottish independence referendum. Journal of Elections, Public Opinion and Parties, 26(3), 354-372.

Mullinix, K. J., Leeper, T. J., Druckman, J. N., \& Freese, J. (2016). The generalizability of survey experiments. Journal of Experimental Political Science, 2(2), 109-138.

Peeters, G., \& Czapinski, J. (1990). Positive-negative asymmetry in evaluations: The distinction between affective and informational negativity effects. European Review of Social Psychology, 1(1), 33-60.

Qvortrup, M. (2005). A comparative study of referendums: Government by the people. Manchester: Manchester University Press.

Rozin, P., \& Royzman, E. B. (2001). Negativity bias, negativity dominance, and contagion. Personality and Social Psychology Review, 5(4), 296-320.

Ruth, S. P., Welp, Y., \& Whitehead, L. (2017). Let the people rule: Direct democracy in the twenty-first century. Colchester: ECPR Press.

Schneider, T. R., Salovey, P., Apanovitch, A. M., Pizarro, J., McCarthy, D., Zullo, J., \& Rothman, A. J. (2001). The effects of message framing and ethnic targeting on mammography use among low-income women. Health Psychology, 20(4), 256-266.

Schuck, A. R. T., \& De Vreese, C. H. (2006). Between risk and opportunity. News framing and its effects on public support for EU enlargement. European Journal of Communication, 21(1), 5-32.

Slothuus, R., \& De Vreese, C. H. (2010). Political parties, motivated reasoning, and issue framing effects. The Journal of Politics, 72(3), 630-645.

Soroka, S. N. (2006). Good news and bad news: Responses asymmetric information to economic information. The Journal of Politics, 68(2), 372-385.

Soroka, S. N. (2014). Negativity in democratic politics. Causes and consequences. New York, NY: Cambridge University Press.

Steele, A. (2017). Democracy and displacement in Colombia's civil war. Ithaca, NY: Cornell University Press.

Taber, C. S., \& Lodge, M. (2006). Motivated skepticism in the evaluation of political beliefs. American Journal of Political Science, 50(3), 755-769.

Tolbert, C. J., Grummel, J. A., \& Smith, D. A. (2001). The effects of ballot initiatives on voter turnout in the 
American states. American Politics Research, 29(6), 625-648.

Vargas, J. F., \& Caruso, R. (2014). Conflict, crime, and violence in Colombia. Peace Economics, Peace Science and Public Policy, 20(1), 1-4.

Verge, T., Guinjoan, M., \& Rodon, T. (2015). Risk aversion, gender, and constitutional change. Politics \& Gender, 11(3), 499-521.

Walker, M. C. (2003). The strategic use of referendums. New York, NY: Palgrave Macmillan.

Weintraub, M., Vargas, J. F., \& Flores, T. E. (2015). Vote choice and legacies of violence: evidence from the 2014 Colombian presidential elections. Research \& Politics, 2(2).

Welp, Y., \& Lissidini, A. (2016). Democracia directa, poder y contrapoder: Análisis del referendo del 21 de febrero de 2016 en Bolivia [Direct democracy, Power and Counter-power: An analysis of the February 21, 2016 referendum in Bolivia]. Bolivian Studies Journal/Revista de Estudios Bolivianos, 22, 162-190.

Zaller, J. (1992). The nature and origins of mass opinion. Cambridge: Cambridge University Press.

\section{About the Authors}

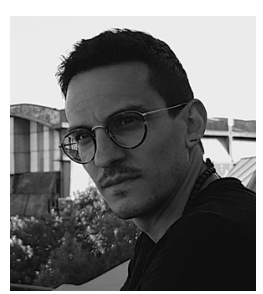

Juan Masullo (PhD, EUI) is Lecturer in the Department of Politics and International Relations and Associate Member of Nuffield College at the University of Oxford. His research interests include individual and collective behaviour in armed conflicts, civilian protection, and citizens' attitudes towards policies to resolve conflict and combat crime. Before joining Oxford, he was Postdoctoral Fellow at the Bremen International Graduate School of Social Science and Research Fellow at Yale's Program on Order, Conflict and Violence.

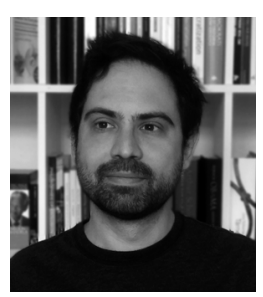

Davide Morisi is an Assistant Professor in political science at Collegio Carlo Alberto in Turin (Italy). His research focuses on political behaviour, public opinion, and political psychology, with a specific focus on direct democracy and referendum campaigns. Davide obtained his PhD at the European University Institute in 2016. He has held positions as postdoctoral researcher at University of Vienna, and as visiting researcher at New York University, Copenhagen University, and University of Edinburgh. 
Appendix A. Study 1 (LAPOP), analysis.

Table A1. Summary statistics.

\begin{tabular}{lcc}
\hline & Percentage & (out of total N) \\
\hline Intend to vote Yes & 39.4 & $(1296)$ \\
Intend to vote No & 20.8 & $(1296)$ \\
Would not vote & 39.8 & $(1296)$ \\
\hline High knowledge (versus low) & 34.7 & $(1356)$ \\
\hline Females & 50.0 & $(1356)$ \\
\hline Income (1st quintile) & 19.8 & $(1356)$ \\
Income (2nd quintile) & 15.3 & $(1356)$ \\
Income (3rd quintile) & 21.2 & $(1356)$ \\
Income (4th quintile) & 17.3 & $(1356)$ \\
Income (5th quintile) & 13.7 & $(1356)$ \\
Income (missing) & 12.7 & $(1356)$ \\
\hline Personal economic situation got better & 25.9 & $(1346)$ \\
Personal economic stayed the same & 43.2 & $(1346)$ \\
Personal economic situation got worse & 31.0 & $(1346)$ \\
\hline Voted for Santos in 2014 & 32.6 & $(1345)$ \\
Voted for Zuluaga & 8.5 & $(1345)$ \\
Voted for other candidate & 20.1 & $(1345)$ \\
Did not vote & 38.8 & $(1345)$ \\
\hline & Mean & St. dev \\
\hline Perception of political knowledge: & 0.50 & 0.23 \\
5 categories, from 0 (very low) to 1 (very high) & & \\
Frequency of attention to news in the media: & 0.84 & 0.27 \\
5 categories, from 0 (never) to 1 (daily) & & 15.13 \\
Age (from 18 to 88) & 39.52 & 4.22 \\
\hline Years of schooling (from 0 to 18) & 9.75 & 0.32 \\
\hline Trust in the president (from 0 to 1) & 0.32 & \\
\hline
\end{tabular}


Table A2. Determinants of intentions to vote Yes to the peace agreement (logistic regressions).

\begin{tabular}{|c|c|c|c|c|c|c|}
\hline \multirow[b]{3}{*}{ High knowledge } & \multicolumn{6}{|c|}{ Intentions to vote Yes } \\
\hline & \multicolumn{2}{|c|}{ (1) } & \multicolumn{2}{|c|}{$(2)$} & \multicolumn{2}{|c|}{ (3) } \\
\hline & $0.103^{* *}$ & $(0.035)$ & $0.112 * *$ & $(0.035)$ & $0.086 * *$ & $(0.032)$ \\
\hline (odd ratios) & $1.564 * *$ & $(0.238)$ & $1.639 * *$ & $(0.255)$ & $1.594^{*}$ & $(0.288)$ \\
\hline (log odds) & $0.447^{* *}$ & $(0.152)$ & $0.494^{* *}$ & $(0.156)$ & $0.466^{*}$ & (0.181) \\
\hline Gender (female) & $-0.086^{* *}$ & $(0.027)$ & $-0.087 * *$ & $(0.027)$ & $-0.066 * *$ & $(0.025)$ \\
\hline Age & $0.004 * * *$ & $(0.001)$ & $0.004^{* * *}$ & $(0.001)$ & 0.001 & $(0.001)$ \\
\hline Education (years of schooling) & -0.002 & $(0.004)$ & 0.001 & $(0.004)$ & 0.007 & $(0.004)$ \\
\hline \multicolumn{7}{|l|}{ Income (ref = 1st quintile) } \\
\hline-2 nd quintile & & & 0.018 & $(0.047)$ & 0.037 & $(0.042)$ \\
\hline - 3rd quintile & & & 0.001 & $(0.043)$ & 0.032 & $(0.040)$ \\
\hline - 4th quintile & & & -0.068 & $(0.045)$ & -0.028 & $(0.042)$ \\
\hline - 5th quintile & & & $-0.098^{*}$ & $(0.040)$ & -0.041 & $(0.041)$ \\
\hline - Unreported/Don't know & & & $-0.116 * *$ & $(0.044)$ & -0.046 & $(0.043)$ \\
\hline \multicolumn{7}{|l|}{ Economic situation (ref = same) } \\
\hline - Got better & & & $0.096 * *$ & $(0.034)$ & $0.061 *$ & $(0.031)$ \\
\hline - Got worse & & & -0.001 & $(0.035)$ & 0.041 & $(0.032)$ \\
\hline Trust in the President (0-1) & & & & & $0.446 * * *$ & $(0.038)$ \\
\hline \multicolumn{7}{|l|}{ Past vote (ref = did not vote) } \\
\hline - Voted for Santos & & & & & $0.207 * * *$ & $(0.036)$ \\
\hline - Voted for Zuluaga & & & & & -0.082 & $(0.042)$ \\
\hline - Other vote & & & & & 0.074 & $(0.040)$ \\
\hline \multicolumn{7}{|l|}{ Interviewed last week } \\
\hline Constant (odds ratio) & $0.359 * *$ & $(0.111)$ & $0.304 * *$ & $(0.104)$ & $0.100 * * *$ & $(0.036)$ \\
\hline $\mathrm{N}$ & \multicolumn{2}{|c|}{1283} & \multicolumn{2}{|c|}{1275} & \multicolumn{2}{|c|}{1261} \\
\hline
\end{tabular}

Notes: $* p<0.05, * * p<0.01, * * * p<0.001$. Coefficients are average marginal effects (except where otherwise specified) based on logistic regressions, with standard errors in parentheses. Dependent variable: intention to vote Yes in the peace agreement referendum versus other choice. High knowledge equal to correct response to three questions on factual political knowledge (for question wording see Appendix B). Stratified estimate using svyset command in Stata (number of strata =6; number of unit per strata $=62$ ). The sample was selected with a multi-stage probability design, using geographical regions, municipality size, and urbanization as the main strata. Respondents were selected in clusters for urban and rural areas. Within each cluster, six participants (three male, three female, divided into three age groups) were randomly selected. 
Table A3. Determinants of intentions to vote Yes to the peace agreement (additional models).

\begin{tabular}{|c|c|c|c|c|c|c|}
\hline \multirow[b]{3}{*}{ High knowledge } & \multicolumn{6}{|c|}{ Intentions to vote Yes } \\
\hline & \multicolumn{2}{|c|}{ (1) } & \multicolumn{2}{|c|}{ (2) } & \multicolumn{2}{|c|}{ (3) } \\
\hline & $0.075^{*}$ & $(0.031)$ & $0.075^{*}$ & $(0.031)$ & $0.076^{*}$ & $(0.032)$ \\
\hline Gender (female) & $-0.059 *$ & $(0.025)$ & $-0.059 *$ & $(0.025)$ & $-0.060 *$ & (0.025) \\
\hline Age & 0.001 & $(0.001)$ & 0.001 & $(0.001)$ & 0.001 & $(0.001)$ \\
\hline $\begin{array}{l}\text { Education (years of schooling) } \\
\text { Income (ref = 1st quintile) }\end{array}$ & 0.007 & $(0.004)$ & 0.008 & $(0.004)$ & 0.007 & $(0.004)$ \\
\hline-2 nd quintile & 0.028 & $(0.042)$ & 0.027 & $(0.042)$ & 0.027 & $(0.042)$ \\
\hline - 3rd quintile & 0.038 & $(0.038)$ & 0.038 & $(0.038)$ & 0.037 & (0.038) \\
\hline-4 th quintile & -0.011 & $(0.042)$ & -0.012 & $(0.042)$ & -0.014 & $(0.041)$ \\
\hline-5 th quintile & -0.039 & $(0.041)$ & -0.036 & $(0.041)$ & -0.039 & (0.041) \\
\hline $\begin{array}{l}\text { - Unreported / Don't know } \\
\text { Economic situation (ref = same) }\end{array}$ & \multicolumn{5}{|c|}{ Economic situation (ref = same) } & $(0.044)$ \\
\hline - Got better & $0.065^{*}$ & $(0.030)$ & $0.064 *$ & $(0.030)$ & $0.066^{*}$ & $(0.031)$ \\
\hline - Got worse & 0.059 & $(0.033)$ & 0.058 & $(0.033)$ & 0.055 & $(0.033)$ \\
\hline Trust in the President (0-1) & $0.249 * * *$ & $(0.050)$ & $0.250 * * *$ & $(0.050)$ & $0.249 * * *$ & $(0.050)$ \\
\hline \multicolumn{7}{|l|}{ Past vote (ref $=$ did not vote) } \\
\hline - Voted for Santos & $0.177^{* * *}$ & $(0.034)$ & $0.176 * * *$ & $(0.034)$ & $0.178 * * *$ & $(0.034)$ \\
\hline - Voted for Zuluaga & -0.079 & $(0.042)$ & -0.080 & $(0.042)$ & -0.078 & $(0.042)$ \\
\hline - Other vote & 0.071 & $(0.040)$ & 0.070 & $(0.040)$ & 0.069 & (0.039) \\
\hline Presidential approval $(0=\min , 1=\max )$ & $0.383 * * *$ & $(0.057)$ & $0.384 * * *$ & $(0.057)$ & $0.385^{* * *}$ & $(0.057)$ \\
\hline Interviewed last week & & & -0.045 & $(0.047)$ & & \\
\hline Day of interview & & & & & -0.001 & $(0.001)$ \\
\hline
\end{tabular}

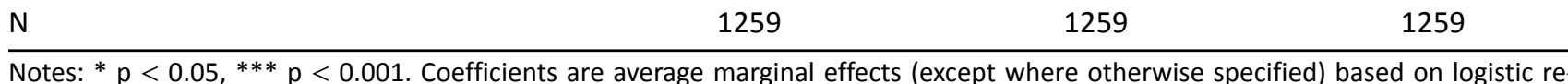
gressions, with standard errors in parentheses. Dependent variable: intention to vote Yes in the peace agreement referendum versus other choice. Presidential approval: five-category variable (including the options "very good", "good", "neither good nor bad", "bad", "very bad"), treated as a continuous variable, with values reversed and rescaled from 0 ("very bad") to 1 ("very good"). Interviewed last week: dummy variable with a value of 1 for those who have been interviewed in between the signature of the referendum in Cartagena (September 27) and the day of the referendum (October 2). Stratified estimates using svyset command in Stata (number of strata $=6$; number of unit per strata $=62$ ). 
Table A4. Alternative measures of political knowledge.

Intentions to vote Yes
(1)
(2)
(3)

\begin{tabular}{|c|c|c|c|c|c|c|}
\hline \multicolumn{7}{|c|}{ Panel A: perceived level of political knowledge } \\
\hline \multicolumn{7}{|l|}{ Perceived knowledge } \\
\hline - Log odds & $0.813^{* *}$ & $(0.250)$ & $0.808 * *$ & $(0.258)$ & $0.762 *$ & $(0.304)$ \\
\hline - Odd ratios & $2.256 * *$ & $(0.564)$ & $2.243^{* *}$ & $(0.578)$ & $2.143^{*}$ & $(0.651)$ \\
\hline - Marginal effects & $0.188 * * *$ & $(0.057)$ & $0.184 * *$ & $(0.058)$ & $0.141^{*}$ & $(0.055)$ \\
\hline $\mathrm{N}$ & \multicolumn{2}{|c|}{1273} & \multicolumn{2}{|c|}{1266} & \multicolumn{2}{|c|}{1252} \\
\hline \multicolumn{7}{|c|}{ Panel B: frequency of attention to news in the media } \\
\hline \multicolumn{7}{|l|}{ Attention to news } \\
\hline — Log odds & $0.679 * *$ & $(0.246)$ & $0.709 * *$ & $(0.255)$ & $0.595 *$ & $(0.278)$ \\
\hline - Odd ratios & $1.972 * *$ & $(0.485)$ & $2.033^{* *}$ & $(0.518)$ & $1.813^{*}$ & $(0.503)$ \\
\hline - Marginal effects & $0.156^{* *}$ & $(0.056)$ & $0.161^{* *}$ & $(0.057)$ & $0.110^{*}$ & $(0.050)$ \\
\hline $\mathrm{N}$ & \multicolumn{2}{|c|}{1281} & \multicolumn{2}{|c|}{1273} & \multicolumn{2}{|c|}{1259} \\
\hline Demographics & \multicolumn{2}{|c|}{ Yes } & \multicolumn{2}{|c|}{ Yes } & \multicolumn{2}{|c|}{ Yes } \\
\hline Income & \multicolumn{2}{|c|}{ No } & \multicolumn{2}{|c|}{ Yes } & \multicolumn{2}{|c|}{ Yes } \\
\hline Economic evaluations & \multicolumn{2}{|c|}{ No } & \multicolumn{2}{|c|}{ Yes } & \multicolumn{2}{|c|}{ Yes } \\
\hline Trust in the President & \multicolumn{2}{|c|}{ No } & \multicolumn{2}{|c|}{ No } & \multicolumn{2}{|c|}{ Yes } \\
\hline Past vote & \multicolumn{2}{|c|}{ No } & \multicolumn{2}{|c|}{ No } & \multicolumn{2}{|c|}{ Yes } \\
\hline
\end{tabular}

Notes: $* \mathrm{p}<0.05,{ }^{* *} \mathrm{p}<0.01,{ }^{* * *} \mathrm{p}<0.001$. Coefficients based on logistic regressions, with standard errors in parentheses. Dependent variable: intention to vote Yes in the peace agreement referendum versus other choice. Perceived knowledge level: 5 categories ("very high", "high", "neither high or low", "low", "very low"), rescaled from 0 (very low) to 1 (very high). Frequency of attention to news in the media: 5 categories ("daily", "some times a week", "some times a month", "rarely", "never"), rescaled from 0 (never) to 1 (daily). The models include the same set of covariates included in Table A2. Stratified estimate using svyset command in Stata (number of strata =6; number of unit per strata $=62$ ).

Table A5. Correlations between knowledge and intentions to vote Yes (vs. No).

\begin{tabular}{lccc}
\hline & & Intentions to vote Yes (vs. No) \\
\cline { 2 - 4 } & $(1)$ & $(2)$ & \\
\hline High knowledge & $0.406+$ & & $(3)$ \\
Perceived knowledge & $(0.216)$ & $0.790 \dagger$ & $(0.422)$ \\
Attention to news & & & 0.536 \\
& & & $(0.364)$ \\
\hline Evaluation of the economy & & Yes & Yes \\
Socio-demographics & Yes & Yes & Yes \\
Trust in the president & Yes & Yes & Yes \\
Past vote & Yes & Yes & Yes \\
\hline $\mathrm{N}$ & Yes & 765 & 767 \\
\hline
\end{tabular}

Notes: $+p<0.1$. Coefficients are log odds based on logistic regressions, with standard errors in parentheses. Dependent variable: intention to vote Yes in the peace agreement referendum versus vote No. Stratified estimate using svyset command in Stata (number of strata $=6$; number of unit per strata $=62$ ). 
Table A6. Correlations between knowledge and voting intentions (multinomial logistic regressions).

\begin{tabular}{|c|c|c|c|c|c|c|}
\hline & \multicolumn{6}{|c|}{ Base category $=$ vote No } \\
\hline & \multicolumn{2}{|r|}{ (1) } & \multicolumn{2}{|r|}{$(2)$} & \multicolumn{2}{|r|}{ (3) } \\
\hline & Vote Yes & Would not vote & Vote Yes & Would not vote & Vote Yes & Would not vote \\
\hline High knowledge & $\begin{array}{c}0.339 \\
(0.224)\end{array}$ & $\begin{array}{c}-0.199 \\
(0.187)\end{array}$ & & & & \\
\hline Perceived knowledge & & & $\begin{array}{c}0.639 \\
(0.395)\end{array}$ & $\begin{array}{c}-0.177 \\
(0.372)\end{array}$ & & \\
\hline Attention to news & & & & & $\begin{array}{c}0.531 \\
(0.332)\end{array}$ & $\begin{array}{c}-0.088 \\
(0.329)\end{array}$ \\
\hline
\end{tabular}

\begin{tabular}{|c|c|c|c|c|c|c|}
\hline & \multicolumn{6}{|c|}{ Base category $=$ would not vote } \\
\hline & \multicolumn{2}{|c|}{ (4) } & \multicolumn{2}{|c|}{ (5) } & \multicolumn{2}{|c|}{ (6) } \\
\hline & Vote Yes & Vote No & Vote Yes & Vote No & Vote Yes & Vote No \\
\hline High knowledge & $\begin{array}{l}0.538 * * \\
(0.188)\end{array}$ & $\begin{array}{c}0.199 \\
(0.187)\end{array}$ & & & & \\
\hline Perceived knowledge & & & $\begin{array}{l}0.816^{* *} \\
(0.330)\end{array}$ & $\begin{array}{c}0.177 \\
(0.373)\end{array}$ & & \\
\hline Attention to news & & & & & $\begin{array}{c}0.619 * \\
(0.308)\end{array}$ & $\begin{array}{c}0.088 \\
(0.329)\end{array}$ \\
\hline Evaluation of the economy & & & & & & \\
\hline Socio-demographics & & & & & & \\
\hline Trust in the president & & & & & & \\
\hline Past vote & & & & & & \\
\hline $\bar{N}$ & & & & & & \\
\hline
\end{tabular}

Notes: $* p<0.05, * * p<0.01$. Coefficients are log odds based on multinomial logistic regressions, with standard errors in parentheses. Dependent variable: voting intentions, including three categories: intention to vote Yes, intention to vote No, and intention not to vote in the peace agreement referendum. Stratified estimates using svyset command in Stata (number of strata $=6$; number of unit per strata $=62$ ).

Table A7. Voting intentions by being a student or not a student.

\begin{tabular}{lcr}
\hline & Not a student & Student \\
\hline Intend to vote Yes & 40.1 & 31.2 \\
Intend to vote No & 20.5 & 23.4 \\
Intend not to vote & 39.4 & 44.3 \\
\hline Total & 100 & 100 \\
\hline (N) & (1183) & (113) \\
\hline
\end{tabular}

Notes: Unweighted percentages. P-value for Pearson's chi-squared test: 0.231. 


\section{COGITATIO}

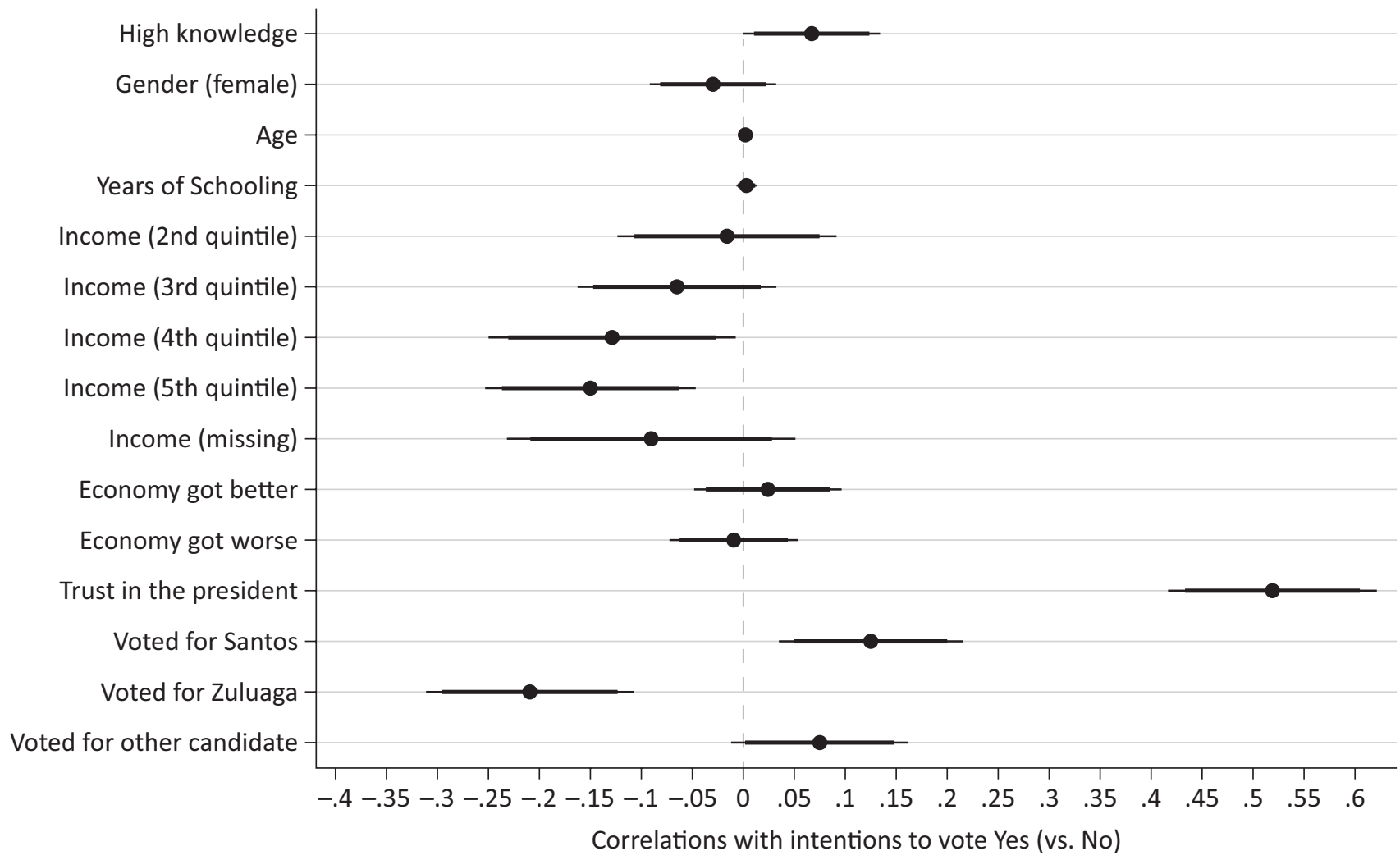

Figure A1. Determinants of intentions to vote Yes (versus vote No) to the peace agreement. Notes: Average marginal effects based on logistic regressions (Model 1 in Table A5, $N=768$ ). Dependent variable: intention to vote Yes in the peace agreement referendum versus vote No. Horizontal lines correspond to 95 percent confidence intervals (thin lines) and 90 percent confidence intervals (thick lines). 


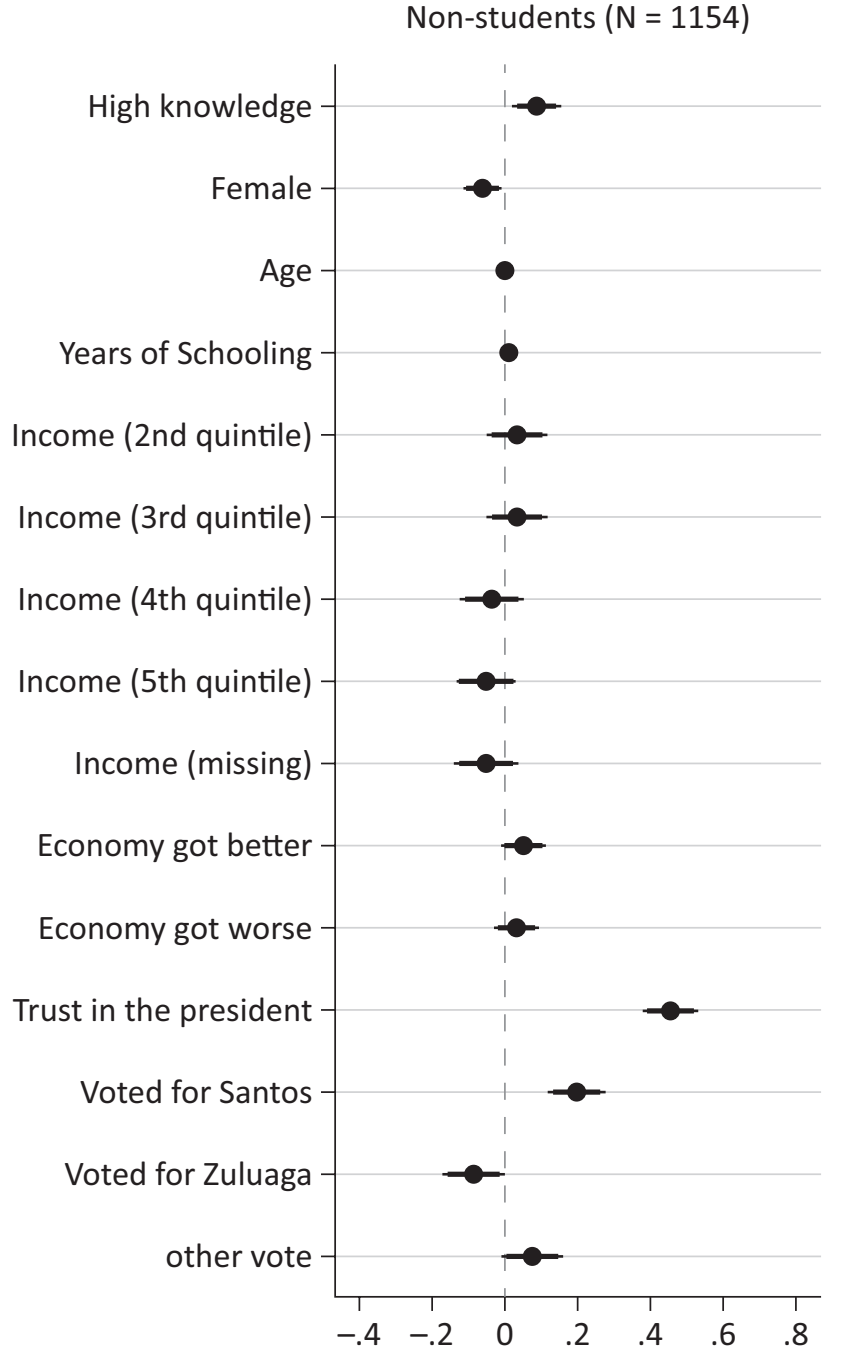

Correlations with intentions to vote Yes

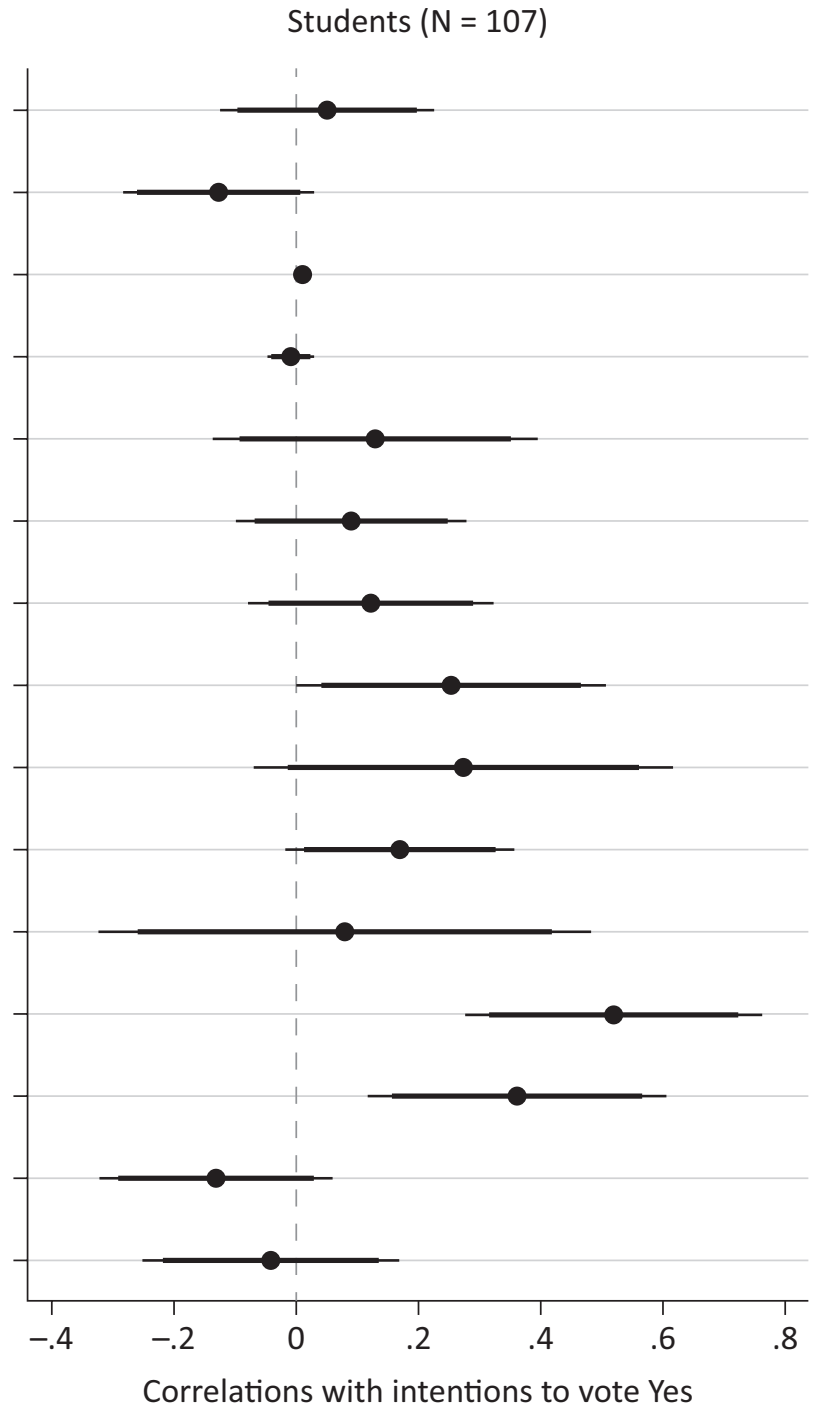

Figure A2. Determinants of intentions to vote Yes for students and non-students (logistic regressions). Notes: Average marginal effects based on the same logistic regression in Model 3 in Table A2, conducted with two separate samples: nonstudents (left-hand panel, $N=1154$ ), and students (right-hand panel, $N=107) 40$ ). Dependent variable: intention to vote Yes in the peace agreement referendum. Horizontal lines correspond to 95 percent confidence intervals (thin lines) and 90 percent confidence intervals (thick lines). 
Appendix B: Study 1 (LAPOP), question wording.

(Authors' own translation. Original wording in Spanish in italics)

Intention to vote in the peace agreement referendum

Q: In the event that a popular vote will be held to endorse the peace agreement between the government and the FARC, how would you vote?

A: I would vote in favor / I would vote against / I would not vote / DK / NA

Q: Y en el evento en que se realizara una votación popular para refrendar el acuerdo de paz entre el gobierno y las FARC, ¿cómo votaría usted?

A: Votaría a favor / Votaría en contra / No votaría / No sabe (no leer) / No responde (no leer)

Factual political knowledge (3 items)

Q: What is the name of the current president of the United States of America?

Q: On what continent is Nigeria?

Q: How long is the presidential term in Colombia?

A: Correct / Incorrect / DK / NA

Q: ¿Cómo se llama el actual presidente de los Estados Unidos de América?

Q: ¿En qué continente queda Nigeria?

Q: ¿Cuánto tiempo dura el período presidencial en Colombia?

A: Correcto / Incorrecto / No sabe (no leer) / No responde (no leer)

Self-reported perceived political knowledge

Q: Using the scale presented below, please rate your perception of your level of political knowledge

A: Very high / High / Neither high nor low / Low / Very low

Q: Usando la escala que se presenta abajo, por favor califique su percepción sobre el nivel de conocimiento político del entrevistado

A: Muy alto / Alto / Ni alto ni bajo / Bajo / Muy bajo

Frequency of attention to news in the media

Q: How often do you follow the news, whether on television, radio, newspapers or the Internet?

A: Daily / Some times a week / Some times a month / Rarely / Never / DK /NA

Q: ¿Con qué frecuencia sigue las noticias, ya sea en la televisión, la radio, los periódicos o el Internet?

A: Diariamente / Algunas veces a la semana / Algunas veces al mes / Rara vez / Nunca / No sabe (no leer) / No responde (no leer)

Personal economic evaluation

Q: Do you think your current economic situation is better, the same or worse than twelve months ago?

A: Better / Equal / Worse / DK / NA

Q: ¿Considera usted que su situación económica actual es mejor, igual o peor que la de hace doce meses?

A: Mejor / Igual / Peor / No sabe (no leer) / No responde (no leer)

Trust in the President

Q: I'm going to ask you a series of questions, and I would like you to answer using the numbers on this scale. Remember that you can use any number. To what extent do you trust the president?

A: 1 (Nothing) / .../ 7 (Much) 
Q: Voy a hacerle una serie de preguntas, y le voy a pedir que para darme su respuesta utilice los números de esta escalera. Recuerde que puede usar cualquier número. ¿Hasta qué punto tiene confianza usted en el presidente?

A: 1 (Nada) / .../7 (Mucho)

Past vote in 2014 presidential election

Q: Did you vote in the last presidential elections of 2014?

A: Yes, I voted / No, I did not vote

Q: Who did you vote for President in the last presidential elections of 2014? [Do not read alternatives]

A: (00) None (went to vote but left the ballot blank) / (97) None (annulled vote) / (801) Clara López / (802) Enrique Peñalosa / (803) Marta Lucía Ramírez / (804) Juan Manuel Santos / (805) Oscar Iván Zuluaga / (877) Other / DK /NA

Q: ¿Votó usted en las últimas elecciones presidenciales de 2014?

A: Sí votó / No votó

Q: ¿Por quién votó para Presidente en las últimas elecciones presidenciales de 2014? [No leer alternativas]

A: (00) Ninguno (fue a votar pero dejó la boleta en blanco) / (97) Ninguno (anuló su voto) / (801) Clara López / (802) Enrique Peñalosa / (803) Marta Lucía Ramírez / (804) Juan Manuel Santos / (805) Oscar Iván Zuluaga / (877) Otro / (888888) No sabe [NO LEER] / (988888) No responde [NO LEER] / (999999) Inaplicable (No votó) [NO LEER] 
Appendix C. Study 2 (experiment), analysis.

Table C1. Summary statistics.

\begin{tabular}{lcc}
\hline & $\begin{array}{c}\text { Frequency } \\
\text { (total N = 478) }\end{array}$ & $\begin{array}{r}\text { Percentage } \\
\text { (total }=100)\end{array}$ \\
\hline Females & 278 & 58.2 \\
High education & 253 & 52.9 \\
Employed (not a student) & 205 & 42.9 \\
Unemployed (not a student) & 69 & 14.4 \\
Student & 204 & 42.7 \\
Living in Bogotá & 313 & 65.5 \\
\hline & Median (mean) & St. dev. \\
\hline Age & 32 (36) & 15.8 \\
\hline
\end{tabular}

Notes: High education corresponds to "Especializacion/maestria" or above.

Table C2. Balance tests (multinomial logistic regression).

\section{Group assignment}

(reference category = control group)

\begin{tabular}{lcccc} 
& $\begin{array}{c}\text { Group 1 } \\
\text { (opportunity-PRO) }\end{array}$ & $\begin{array}{c}\text { Group 2 } \\
\text { (opportunity-CON) }\end{array}$ & $\begin{array}{c}\text { Group 3 } \\
\text { (risk-PRO) }\end{array}$ & $\begin{array}{c}\text { Group 4 } \\
\text { (risk-CON) }\end{array}$ \\
\hline Gender (female) & -0.049 & 0.279 & -0.394 & 0.011 \\
& $(0.315)$ & $(0.319)$ & $(0.310)$ & $(0.313)$ \\
Age & 0.002 & 0.016 & 0.008 & 0.004 \\
& $(0.014)$ & $(0.014)$ & $(0.013)$ & $(0.014)$ \\
High education & -0.081 & -0.404 & -0.302 & $-0.649 *$ \\
& $(0.320)$ & $(0.316)$ & $(0.316)$ & $(0.315)$ \\
Employment (ref = working, not student) & & & & \\
- Unemployed, not student & -0.599 & $-1.158 *$ & -0.743 & -0.595 \\
& $(0.500)$ & $(0.505)$ & $(0.475)$ & $(0.472)$ \\
- Student & 0.230 & -0.082 & -0.107 & -0.178 \\
& $(0.365)$ & $(0.366)$ & $(0.364)$ & $(0.365)$ \\
Living in Bogotá & 0.111 & 0.036 & 0.075 & 0.091 \\
& $(0.329)$ & $(0.326)$ & $(0.322)$ & $(0.327)$ \\
Constant & -0.080 & -0.329 & 0.220 & 0.307 \\
& $(0.695)$ & $(0.695)$ & $(0.663)$ & $(0.674)$ \\
\hline
\end{tabular}

Pseudo $\mathrm{R}^{2}$

.012

$\mathrm{N}$

Notes: ${ }^{*} \mathrm{p}<.05$. Multinomial logistic regression of random assignment to treatment groups on socio-demographic covariates. Coefficients are log odds. Standard errors in parentheses. 
Table C3. Treatment effects on support for peace agreement (average marginal effects).

\begin{tabular}{|c|c|c|c|c|}
\hline & \multicolumn{4}{|c|}{ Intentions to vote Yes } \\
\hline & \multicolumn{2}{|c|}{ (Model 2) } & \multicolumn{2}{|c|}{ (Model 4) } \\
\hline \multicolumn{5}{|c|}{ Treatment groups (ref: control) } \\
\hline \multicolumn{5}{|l|}{ Opportunity (PRO) } \\
\hline - All respondents & $0.090 *$ & $(0.050)$ & & \\
\hline — Low knowledge & & & $0.257^{* * *}$ & $(0.083)$ \\
\hline — High knowledge & & & -0.001 & $(0.059)$ \\
\hline \multicolumn{5}{|l|}{ Opportunity (CON) } \\
\hline - All respondents & 0.032 & $(0.052)$ & & \\
\hline — Low knowledge & & & 0.126 & $(0.094)$ \\
\hline — High knowledge & & & -0.032 & $(0.062)$ \\
\hline \multicolumn{5}{|l|}{ Risk (PRO) } \\
\hline - All respondents & -0.001 & $(0.055)$ & & \\
\hline — Low knowledge & & & 0.062 & $(0.108)$ \\
\hline — High knowledge & & & -0.045 & $(0.062)$ \\
\hline \multicolumn{5}{|l|}{ Risk (CON) } \\
\hline - All respondents & 0.055 & $(0.052)$ & & \\
\hline — Low knowledge & & & 0.149 & $(0.099)$ \\
\hline — High knowledge & & & -0.004 & $(0.058)$ \\
\hline $\mathrm{N}$ & & & & \\
\hline
\end{tabular}

Notes: ${ }^{* *} \mathrm{p}<0.01$. Average marginal effects calculated on logistic regressions in models 2 and 4 in Table 2 . 
Appendix D. Why con arguments did not influence respondents?

We attempted to investigate why the arguments used by the opponents of the referendum did not reduce support for the peace agreement within our sample. A possible explanation concerns the fact that our sample included a large share of supporters of the peace agreement who might have rejected No campaign arguments because they "disconfirmed" what they already believed in. Indeed, we find that those who read a con argument stressing the risks of voting Yes spent more time replying to the voting question compared to the control group (see Table D1 below). This finding supports the idea that the participants engaged in rejecting counter-attitudinal arguments - a so-called "disconfirmation bias" (e.g., Redlawsk, 2002) - and is consistent with the fact that several arguments of the No campaign were intended to cause fear (Arjona, 2016), thus potentially leading to opposite reactions in the Yes camp.

On the other hand, we also find that those who read the risk argument supporting the peace agreement spent more time replying to the voting question. This finding suggests that risk messages in general implied longer information processing, which did not necessarily translate into persuasion, in line with theoretical expectations (Hypothesis $2 b$ ) and with research on negative information (Ito, Larsen, Smith, \& Cacioppo, 1998). In other words, participants might have found the risk arguments more difficult to process and, therefore, also less convincing.

Table D1. Regression of time spent replying to voting question on group assignment.

\begin{tabular}{|c|c|c|}
\hline & \multicolumn{2}{|c|}{ Time spent replying } \\
\hline & (1) & $(2)$ \\
\hline \multicolumn{3}{|l|}{ Treatment groups (ref: control) } \\
\hline \multirow[t]{2}{*}{ - Group 1 (opportunity-PRO) } & -0.951 & -0.748 \\
\hline & $(1.490)$ & $(1.484)$ \\
\hline \multirow{2}{*}{ - Group 2 (opportunity-CON) } & 0.220 & 0.053 \\
\hline & $(1.482)$ & $(1.466)$ \\
\hline \multirow{2}{*}{ - Group 3 (risk-PRO) } & $2.969 * *$ & $3.121 * *$ \\
\hline & $(1.482)$ & $(1.473)$ \\
\hline \multirow{2}{*}{ - Group 4 (risk-CON) } & $4.060 * * *$ & $3.672 * *$ \\
\hline & $(1.474)$ & $(1.465)$ \\
\hline Demographics & No & Yes \\
\hline \multirow[t]{2}{*}{ Constant } & $11.984 * * *$ & $12.649 * * *$ \\
\hline & $(1.048)$ & $(2.552)$ \\
\hline $\mathrm{R}^{2}$ & .035 & .062 \\
\hline $\mathrm{N}$ & 470 & 464 \\
\hline
\end{tabular}

Notes: ${ }^{* *} p<0.05,{ }^{* *} p<0.01$. Coefficients from OLS regressions with standard errors in parentheses. Dependent variable: time spent replying to voting question measured in hundredth of seconds, values trimmed at 1 percent and 99 percent levels. Model 2 includes the same set of covariates included in Model 2 in Table 2. 


\section{COGITATIO}

Appendix E. Study 2 (experiment), question wording and information stimuli.

Main variables used in the experiment (original wording in Spanish in Italics)

\section{Vote}

The question for the upcoming Plebiscite on the 2 nd of October is: "Do you support the Final Agreement for the termination of the conflict and the building of a stable and lasting peace (Art. 1, decree 1391, 2016)". If the Plebiscite was held tomorrow you would vote:
Yes
No
Do not know
Will not vote

La pregunta del Plebiscito del próximo 2 de octubre es: "Apoya usted el Acuerdo Final para la terminación del conflicto y la construcción de una paz estable y duradera? (Art. 1 decreto 1391 de 2016)". Si el Plebiscito fuera mañana, usted votaría:
Sí
No
No sabe
$\square$ No va a votar

\section{Knowledge}

Which of the following was NOT one of the 6 items of the negotiation agenda?
Political participation
Illicit drugs
$\square$ Education policies
Integral agrarian reform
Do not know

¿Cuál de los siguientes NO fue uno de los 6 puntos de la agenda de negociación?
Participación política
Drogas ilícitas
Políticas educativas
Reforma rural integral
No sabe

In which month was the Peace Agreement signed?
September 2016
$\square$ June 2016
April 2016
$\square$ January 2016
Do not know

¿En qué mes se firmó el Acuerdo de paz?
Septiembre 2016
Junio 2016
Abril 2016
Enero 2016
No sabe 
Texts used in the experiment (original wording in Spanish in Italics)

\section{Group 1 (PRO-opportunity)}

Those who support the Yes argue that voting Yes in the Plebiscite is a historical opportunity to end with violence in the country. They assert that it is the key for bringing peace to the rural areas and for the displaced population to return to their lands, without poverty, without landmines and without illicit crops. They anticipate that victims will know what happened with their beloved ones, and reparation and non-recurrence will be guaranteed. They see in the Plebiscite the opportunity to decide whether we want to stop war or continue with it.

Quienes apoyan el Sí sostienen que votar Sí en el Plebiscito es una oportunidad histórica para acabar con la violencia en el país. Afirman que es la clave para llevar la paz al campo y para que los desplazados regresen a trabajar a sus tierras, sin pobreza, sin minas y sin cultivos ilíitos. Anticipan que las víctimas sabrán qué pasó con sus seres queridos, serán reparadas y se les garantizará la no repetición. Ven en el plebiscito la oportunidad para decidir si queremos finalizar o continuar con la guerra.

\section{Group 2 (PRO-risk)}

Those who support the Yes argue that voting No in the Plebiscite would mean throwing away four years of negotiations. They affirm that the No would take us to a blind alley and eventually lead us back to armed confrontation, condemning future generations to more years of war. They highlight that we would lose the trust and support of the international community and predict that the insurgents would not seat again to renegotiate.

Quienes apoyan el Sí sostienen que votar No en el plebiscito sería tirar por la borda cuatro años de negociaciones. Afirman que el No nos conduciría a un callejón sin salida y a un eventual retorno a la confrontación armada, condenando futuras generaciones a más años de guerra. Resaltan que perderíamos la confianza y el apoyo de la comunidad internacional y auguran que la guerrilla no volvería a sentarse a renegociar.

\section{Group 3 (CON-opportunity)}

Those who support the No argue that rejecting the agreements does not mean going back to war. They see it as an opportunity to renegotiate, addressing several aspects of the Agreement that they find problematic and involving other representatives of the society that were not present in the process. They highlight that the No is an opportunity to demand peace with dignity.

Quienes apoyan el No sostienen que rechazar los acuerdos no es volver a la guerra. Lo ven como una oportunidad para renegociar, replanteando varios puntos del Acuerdo que encuentran problemáticos e incorporando otros representantes de la sociedad que no estuvieron presentes en el proceso. Resaltan que el No es una oportunidad para solicitar una paz digna.

\section{Group 4 (CON-risk)}

Those who support the No argue that the agreements are bad for the country. They affirm that if we approve them, impunity will rise as the high commanders of the guerrilla will not go to jail. They also highlight that it would damage democracy as the rebels would be awarded with the possibility of participating in politics. This would go against the Constitution and question fundamental values of our society such as private property.

Quienes apoyan el No sostienen que los acuerdos son perjudiciales para el país. Afirman que de aceptarlos la impunidad en el país incrementaría porque los máximos comandantes de la guerrilla no pagarían cárcel. Resaltan también que se deterioraría la democracia porque a los guerrilleros se les premiaría con la posibilidad de hacer política, lo que atentaría contra la Constitución y pondría en riesgo aspectos fundamentales de la sociedad como la propiedad privada.

\section{References}

Arjona, A. (2016). War dynamics and the "NO" vote in the Colombian referendum. Political Violence at a Glance. Retrieved from http://politicalviolenceataglance.org/2016/10/20/war-dynamics-and-the-no-vote-in-the-colombianreferendum

Ito, T. A., Larsen, J. T., Smith, K. N., \& Cacioppo, J. T. (1998). Negative information weighs more heavily on the brain: The negativity bias in evaluative categorizations. Journal of Personality and Social Psychology, 75(4), 887-900.

Redlawsk, D. P. (2002). Hot cognition or cool consideration? Testing the effects of motivated reasoning on political decision making. The Journal of Politics, 64(4), 1021-1044. 